\title{
Resisting Neo-Liberal Skylines: Social Mobilisations and Entrepreneurial Urban Development in Tel Aviv
}

\author{
Adriana Kemp and Talia Margalit
}

\begin{abstract}
The article examines recent social mobilisations against the planning and building of towers in Tel Aviv to address ongoing debates over the impact of social activism on the neo-liberalisation of urban development in times of neoliberalism's 'legitimation crisis.' Contrary to binary views of 'neoliberalism vs. resistance' prevalent in scholarly debates, we look into the uneven ways in which urban mobilisations are conditioned by local configurations of neo-liberalisation, and how, in their turn, they affect neoliberal practices as they oscillate between resistance and integration. Based on empirical analysis, we argue that while recent mobilisations introduced novel claims and tactics against the institutional methods and decisions that produce urban space, and succeeded in politicizing towers as the flagship of neoliberal urban development, their actions have been reinserted in the deepening neo-liberalisation of the city. Our findings raise broader insights about the ways in which neo-liberalisation processes sit inside society and not above it, as they shape the actors concerned, their positions, and their visions of development.
\end{abstract}

\section{Introduction}

In summer 2011 expensive residential towers in Tel Aviv became visibly synonymous with social injustice when thousands of demonstrators waved mocksups of the flashy towers that were sprawling across the city, while marching to protest against the high cost of food, housing, health and education. This massive protest was the first to highlight the popular local struggle against the changing skyline of Tel Aviv as a symptom of broader social discontent with the 'trickle-down' promises of neo-liberal development.

The young leaders of the protest, and the thousands that joined them in numerous tent cities, identified the sharp escalation of urban accommodation costs as the main social crisis of their generation: since the late 1970s,

(C) ADRIANA KEMP AND TALIA MARGALIT, 2017 | DOI 10.1163/9789004349551_008

This is an open access chapter distributed under the terms of the preyailing CC-BY-NC license at the time of publication. 
the government had stopped building affordable housing and the reservoir of public housing had dried up. No laws protect tenants, and many fear of being pushed out of the city's apartments, and of jobs, and of society itself (Alfasi and Fenster, 2014; Margalit, 2014; Marom, 2014). Like in other contemporary 'Occupy' campaigns worldwide, protesters denounced the symbolic and material links between the building of elitist towers and the ongoing political agendas that, in recent decades, have forcefully promoted the narrow set of interests of a small elite (see Peck et al., 2013; Aalbers, 2013; Sklair and Gherardi, 2012) while neglecting other groups' pressing needs (Schipffer, 2015).

Inspired by the 2011 'social justice' protests, and leveraging the momentum that those protests created towards bolder and more politicised forms of activism, several groups of residents, activists and planning professionals organised opposition to the planning and building of towers as the flagship of urban development in Tel Aviv. In this paper, we analyse two of these mobilisations as a starting point for addressing ongoing debates on the impact of social activism on the neo-liberalisation of urban space in the current moment of neoliberalism's 'legitimation crisis'.

Broadly speaking, critical scholarship on urban development and the 'right to the city' (Purcell, 2003) underscores how the subordination of urban space to speculative profit making at the expense of use values, social needs, and public goods has resulted in a rise in the regularity with which the political legitimacy of neo-liberal policies is challenged (see Burningham and Thrush, 2001; Ellis, 2004; Dixon 2010). Central to these approaches is an emphasis on the counter-hegemonic power of urban mobilisations against corporate market rule, especially since the Occupy and 15 -M movements diffused into many of the urban strongholds of neo-liberalism. However, much of this scholarship also tends to overlook how social movements' struggles may actually advance neo-liberalisation or remain trapped in its sweeping logic (for such a critique, see Blokland et al., 2015). Conversely, political economy approaches highlight the structural market forces underlying the neo-liberal towering skylines, but largely disregard the significance of social protest and how it is being transformed (Fuller, 2012).

Contrary to celebratory portrayals of current mobilisations claiming rights to and through the city (Nicholls and Vermeulen, 2012), but also to agonistic diagnoses of the overriding power of neo-liberalism as a coherent project, we suggest going beyond binary views of 'neo-liberalism vs. resistance.' Following Margit Mayer (2013), we offer a more nuanced and contextualised analysis of the mutually constitutive relations between actual existing mobilisations and urban neo-liberalisation as a starting point for rethinking the dialectics between development (as an ideological project, a form of governance, and a 
form of social action) and conflict. According to Mayer (2013), the unfolding of the financial and political crisis in the Global North and South has created new tactics, broader redistributive claims, and more heterogeneous coalitions between the 'discontented' urbanite middle classes and 'dispossessed' social groups (Marcuse quoted in Mayer, 2013, 4) than the 'new social movements' and professionalised mobilisations of preceding decades. Yet, as she points out, despite general trends, we are yet to uncover the uneven ways in which these mobilisations are conditioned by local configurations of neo-liberalisation and ensuing visions of what is possible or even desirable, and how, in their turn, social mobilisations affect neo-liberal practices as they oscillate between resistance and integration (Künkel and Mayer, 2012, 3).

Drawing on the understanding that neither neo-liberalisation nor its challenges are uniform or external to each other (Peck et al., 2009), this chapter compares two types of mobilisation that emerged with respect to towers in Tel Aviv amid the context of broader social protest: the first concerns two towers that were planned close to a gentrified, upscale neighbourhood (Yitzhak Elhanan Projects); ${ }^{1}$ the second concerns the privately-owned public spaces (POPS) built around towers throughout the city. We chose these mobilisations because, unlike previous NIMBY- and aesthetics-related objections, they posed principled challenges to core dimensions of entrepreneurial urban development policies: the financing of public services through the exaction of side benefits, case-deal negotiations with private developers and the privatisation of public spaces.

To examine the types of challenges to urban development that are emerging, we ask the following questions: Who are the challengers in terms of their social positions? Which policies are they challenging and by what means? How do they frame the conflictual aspects of urban development? And what counterclaims do they raise? Finally, to understand the type of 'crisis' they are alluding to, we analyse current social mobilisations in the context of the longer history of socio-economic restructuring in which they are embedded. Therefore, we examine current forms of resistance as building upon, reiterating, or

1 Empirical data on both cases are based on personal interviews with key activists and on the systematic tracking and analysis of a variety of documentary sources: newspapers' publications, court petitions and court verdicts, planning authorities' protocols, personal e-mail correspondence between the activists (in the case of Yitzhak Elhanan), and activists' Facebook pages and blogs (in the case of POPs). The empirical analysis is part of wider joint research into objections to, and justifications of, planning decisions, and social stratification in eight different cities situated across the socio-economic and ethno-national spectrum of Israeli society—research funded by the Israel Science Foundation (ISF 1080/13). 
challenging those previous repertoires of mobilisation that evolved during recent decades in the wake of new forms of deep neo-liberalisation of urban development.

Based on our analysis, we suggest that while recent mobilisations have introduced novel claims and tactics against the institutional methods and decisions 'that produce urban space' and have succeeded in politicising towers as the flagship of neo-liberal urban development, their actions have remained trapped in the fragmented dynamics of neo-liberalisation. By failing to connect discursively and strategically the conflicts created by entrepreneurial development, we argue, current mobilisations tell more about the particular crises of the social groups that they represent than they do about the systemic crisis of neo-liberalism itself. In that sense, our findings raise broader insights into the ways in which neo-liberalisation processes sit inside society and not above or against it, as they shape the actors concerned, their positions, and the ways in which they imagine what development is or can be.

The chapter is organised as follows: first, we introduce a critical analysis of urban entrepreneurial development, the institutional justifications of towers, and their critiques; the second section examines the path-dependent course of urban neo-liberalisation and tower planning and building in Tel Aviv; the third section analyses our case studies of counter-mobilisation. In the final section, we discuss the implications of our study for current debates on conflicts in and about urban development.

\section{$2 \quad$ Neo-Liberal Urban Development, Institutional Justifications of Towers, and Their Critiques}

Neo-liberalisation is a shorthand description of processes that deepen marketoriented behaviours, institutions and regulations (Brenner et al., 2010). At the urban level, neo-liberal or 'entrepreneurial' development represents a mode of socio-economic regulation that incentivises market agents to invest, develop, and create workplaces, infrastructure, and social and spatial amenities (Harvey, 1989; Swyngedouw et al., 2002; Enright, 2014). The preliminary push to urban entrepreneurialism came in the 1970s, as municipalities in the US and UK faced bankruptcy due to the severe cutbacks of federal aid (Tasan-Kok, 2008; Theodore et al., 2011). To support public budgets and encourage private investment, municipalities both privatised centrally located public land and advanced megaprojects (Fainstein, 2008; Sagalyn, 2007). In the following decades, the linkage between privatisation, flexible planning, expensive development and urban finances became common to many cities, together with 
the 'trickle-down' promise that liberation from state interference would lead to optimal economic operation and benefit all parts of society (Harvey, 2005). In this context, a family of planning methods gained importance. It included flexible, local spot-zoning amendments to statutory planning schemes, made with the purpose of advancing site-specific projects and public-private (PP) ventures. To this end, authorities strike specific planning 'deals' with private actors that allow the exchange of public goods and tasks - 'side benefits'-for extra floor rights (Fainstein, 2008; Tasan-Kok, 2008; Alfasi, 2006; Sagalyn, 2007; Margalit, 2014; Fox-Rogers and Murphy, 2015).

The increase of high-rise ventures designed for local and international elites (Sklair and Gherardi, 2012) was intimately linked to entrepreneurial paradigms of urban growth and development. Famously defined as 'a machine that makes the land pay more' (the architect Cass Gilbert, 1901, in Willis, 1995, 19), more tall towers have been planned in recent years than at any time previously in Asia, the America and Europe (Leiper and Park, 2010). The systemic preference for high towers has been legitimised by an array of ideological and practical justifications that invoke the master frame of 'the public interest' (Alexander, 2002). Advocating the belief that 'market and business rationality can be made to operate as effectively in the public interest as it does in securing private interests' (Sager, 2011, 153), planning and municipal authorities offer spatial and economic incentives for building expensive projects as a means of urban revival and beautification. As new hubs 'of a radiating renaissance', these projects are said to facilitate increases in land values to adjacent areas (Loftman and Nevin, 1995, 300) and the 'trickle down' of prosperity to the local economy (Fox Gotham, 2001, 14). Entrepreneurial practices are further legitimised as a social must in an era of global intercity competition, with the argument that 'corporations today have the economic and political power to take their investments elsewhere should local officials not prove compliant' (Fox Gotham, 2001, 16).

The 'flexibilisation' of planning and its subjection to market rule is also justified by public officials' need 'to get things done', thereby signalling economic success and political efficiency to different constituencies (Stone, 1993). This agenda is vindicated in terms of past failures, mostly related to the failed outcomes of 'rigid' Keynesian direct public spending on urban redevelopment and housing programmes (Aalbers, 2013). In this way, municipal authorities extend generous building rights to private developers in exchange for the financing of public tasks such as affordable housing, open spaces, heritage preservation, infrastructure and the like (Sagalyn, 2007; Tasan-Kok, 2008). This semi-opaque practice of striking deals with private developers is justified by the need to compensate communities for the disruptions incurred by 
the building of megaprojects and the need to cover the costly infrastructure required while keeping back public funds for other, less profitable areas and tasks (Alterman, 1990). Thus, urban communities are said to enjoy, in practical terms, side benefits channelled through budgetary and spatial reallocation, even if their involvement in the details of the negotiations is mostly minimal (Tasan-Kok, 2008).

Entrepreneurial policies have sparked several academic critiques for deepening uneven spatiality and socio-economic inequality. Urban theorists have criticised P P ventures for 'reclaiming' public spaces only for groups who possess economic value (Heeg and Rosol, 2007; Sager, 2011), and distancing themselves from areas where needs are great but the probability of value extraction is slight (Weber, 2002). Instead of activating other plans and redistributing investment, this project-based growth strategy extends the easing of regulation to attract more massive and expensive projects. According to Fainstein (2008), as such projects are the only ones that can generate the profits needed to finance complex municipal demands, smaller, less expensive or long-term programmes are postponed. One of the results of this is the creation of 'prosperity clusters', socially and economically segregated from nearby neighbourhoods and from wider urban society (Graham and Marvin, 2001, 222).

Another line of critique goes against the claim that flexible planning methods accelerate the bureaucratic process and avoid political favouritism. Scholars note that far from the illusion of free market competition, entrepreneurial ventures intensify political intervention and arbitrariness (Aalbers, 2013), as governments often facilitate one set of agents in market transactions, identifying them as the sole engine of urban growth and wealth (MacLeod, 2002; Brenner and Theodore, 2002). Likewise, spot-zoning techniques informed by individual decisions (Booth, 1995) benefit mainly large investors and large projects by singling them out 'for preferential treatment' (Cullingworth, 1993, 49).

Finally, critics also point to the power differentials that shape the negotiations between the developer and the 'public'. These negotiations are managed by local government, which plays the double role of regulator and economic stakeholder (Sagalyn, 2007; Gielent and Tasan-Kok, 2010), and is often eager to maintain a 'good business' atmosphere by making compromises that work mostly for the benefit of private developers (Margalit, 2013 and 2014; FoxRogers and Murphy, 2015). Negotiating public goods is even harder when flexible planning and 'deal-making' are used as commercial assets for municipal governments' global competitive agendas (Tasan-Kok, 2008).

With no alternatives offered, the business logic of neo-liberalisation has become 'doxic "commonsense" that utilises flexible development to foster its own 
institutionalisation (Keil, 2009; Peck et al., 2013, 1094). Yet, the entrepreneurial city and its growing vertical architecture have ignited broadening waves of urban social protest across the globe. Scholarship on social mobilisations in urban settings stretching from Saint Petersburg (Dixon, 2010), through Buenos Aires (Crot, 2006) and Tokyo (Saito, 2003), to cities on the Pacific Rim (Marshall, 2003), demonstrate that towers are increasingly interpreted as a spatial signifier of corporate power, gentrification and inequality (see Burningham and Thrush, 2001; Grubbauer, 2014). The case of Tel Aviv-Jaffa exemplifies these dynamics of deepening neo-liberalisation and mounting discontent. Yet as we will now show, the local case has some particularities, as both the development of 'entrepreneurial' towers and the critiques against it have followed their own path dependency, pointing towards the hybrid nature of neo-liberal urban development but also towards the contextual nature of counter-mobilisations as part of a longer history of neo-liberalisation.

'Entrepreneurial Centralism' and the Politics of Towers in Tel Aviv-Jaffa

Contemporary Tel Aviv-Jaffa with its 400,00o residents is the centre of a 'metro region' inhabited by three million people. The city is historically divided along clear socio-economic and ethno-national lines, with most of the affluent quarters located to the north and settled by mainly European Jews, while the poor quarters remain the southern quarters and in those in Jaffa where Arabs and Jews originating from the Middle East and North African countries live (Marom, 2014). The vertical socio-spatial divisions have evolved since the $1950 \mathrm{~s}$ and have gradually magnified the uneven local socio-economic cartography. Today, mid-height constructions (three-six floors) compose most of the urban built fabric, with dotted enclaves of higher constructions (eight-14 floors) and taller towers $\left(15^{-50}\right.$ floors) mainly located in the affluent northern quarters, and some 'high-end' central locations (Margalit, 2013, 377).

Although projects are spread out across the urban layout and appear to be isolated, they are the result of a complex structure of entrepreneurial methods and policies that have been layered through dozens of spot-planning deals struck by consecutive urban regimes. Indeed, since the establishment of the state of Israel and the creation of the national Israeli Land Administration (ILA), a foremost particularity of the urban development scene in Tel Aviv (and more broadly in Israel) has been its 'entrepreneurial centralism'. While in the us and Western European countries, post-Keynesian restructuring resulted in a significant decrease in central land management and centralistic-hierarchic 
planning, the Israeli land and planning regimes combine a high degree of spatial management centralisation and market entrepreneurialism. 'City Hall' and the national bureaucracy continue to play a leading role in the development regime as, simultaneously as landowners, entrepreneurs and regulators, while at the same time adapting state-of-the-art tactics of extraversion such as PP ventures, case-and-deal making, and private financing of public tasks. The map of high-rises in Tel Aviv reflects this particularity. An examination of their development in the city shows that, with almost 70 per cent of the urban land assets in Tel Aviv-Jaffa centrally managed and owned, the seeds of entrepreneurial planning were planted in the 1950s, when the socialist Labour Party led both the national government and the city (Margalit, 2013). Until the 1990s, plans for high-rises were mainly issued for plots owned, managed and planned by either the ILA or the Tel Aviv Municipality and then assigned by the city and/or the government to private entrepreneurs through a combination of 'flexible' practices (Margalit, 2013). These practices are still dominant in the planning of towers today, along with the encouragement for large private landowners to build high-rise towers, mainly for affluent citizens or large companies, or as hotels.

Throughout the 1990s, as several flashy projects of historic preservation and the urban renewal of the old Central Business District (СвD) were advanced by city planners, the methods for achieving side benefits and the obligations to finance and develop public spaces were extended (Margalit, 2014). Since 1998 to date, Mayor Ron Huldai's administration has solidified these practices albeit in many more and much higher tower schemes, and presented preservation, open spaces, and infrastructure improvements as the leading elements of towers developers' obligations. The side benefits are channelled mainly to urban beautification, and tower ventures have been justified as beneficial to the public in terms of 'the actual design and the supply of public spaces for the neighbourhood residents.'2 In this manner, dozens of site-specific schemes were negotiated as specific planning deals, where planners obligated developers to finance and execute spatial improvements in exchange for extended heights and building rights in prime locations. ${ }^{3}$

2 Tel Aviv Regional Planning Committee, decision protocols for schemes no. 3753 and 3853; http://mavat.moin.gov.il/MavatPS/Forms/SV3.aspx?tid=3 (accessed on 28 July 2016).

3 See for example scheme no. 2650a. Following the nomination of the White City of central Tel Aviv as a World Heritage site in 2003, the scheme encouraged the owners of historical buildings to sell air rights to developers. Such transactions were explained in the statutory documents by 'the need to preserve this building and assure its usage for tourism.' http://gisn .tel-aviv.gov.il/iview2/ (accessed on 28 July 2016). 
Currently, the planning and construction of towers in Tel Aviv dramatically exceeds earlier cycles in terms of the number of buildings, their height and their price. With an average of 30 stories per tower, this new cycle has changed the residential landscape and the levels of real estate prices, and has surpassed the previous scale of high-rise construction. ${ }^{4}$ At the same time, a strip of only 500 metres separates the most fashionable tall hubs of the city from the southern neighbourhoods that most locals see as the city's backyard (Kemp and Raijman, 2004), and only a ten-minute drive separates them from the poor Arab and Jewish neighbourhoods in Jaffa. There, despite sprawling gentrification and beautification efforts (mainly along the beachfront areas) (Marom, 2014; Monterescu, 2009), most residents still rank lower on all socio-economic and environmental indicators, and planning projects hardly materialise in this area (Marom, 2014; Margalit and Vertes, 2015). ${ }^{5}$

The local situation thus echoes the conflictual side of towers and other neo-liberal megaprojects in other contexts where towers are seen as transforming space into prestige sites that generate both financial and cultural capital (Vicario and Monje, 2003), erasing urban diversity through the creation of homogeneous spaces that serve a limited area and the particular interests and visions of elite groups (Saito, 2003; Crot, 2006), marginalising alternative uses of space closer to the needs of everyday existence (Dirlik, 2005), triggering identity struggles (Dixon, 2010), and non-democratic megalomania (McNeill, 2002). Moreover, we find that as the scope of entrepreneurial practices in Tel Aviv expanded, the semantic field of 'public interest' considerably narrowed to align itself with the particular aesthetics and needs of affluent and cosmopolitan city dwellers, tourists, and wannabe Tel Avivians. What has nonetheless changed in the current phase of neo-liberal development is the emergence of broader social protest denouncing the ways of 'gettingthings-done' through tower construction. In the following, we analyse these contestations.

4 The Huldai Administration has so far issued 53 site-specific spatial schemes for 118 highstandard residential towers, of which 50 have already been completed or are under construction. For comparison, between the mid-196os and 2002, only 46 high-standard residential towers of 15 floors or more were built in the entire city, 18 of which were built in the centre, with the luxury facilities now common (Margalit, 2013). In addition, many proposed office towers and hotels received permits and were built, and a large new northern suburb was built with mid-height, upscale residences along the seashore.

5 The southern quarters rank lower on all socio-economic and environmental indicators than the rest of the city (Margalit and Vertes, 2015). 
The planning and building of towers in Tel Aviv have been the objects of criticism and objections throughout the years. ${ }^{6}$ When the municipality tailored its policies with regards to tower construction to the historic $\mathrm{CBD}$ and the beach strip in the late 1990s, criticism escalated but those policies typically focused on specific locations and schemes that aimed to utterly alter the old СвD area (Hatuka and Forsyth, 2005). Although some journalists criticised the elitist inclinations of municipal politicians, in the following decade local communities mostly proceeded by objecting to particular planning schemes in their areas. For years, the limited scope of objections and the ways in which they were framed mirrored the entrepreneurial method of development: based on 'not in my back yard' (NIMBY) and heritage preservation arguments concerning specific ventures, these protests reflected the fragmented nature of spotzoning and case-deals policies, while leaving intact institutional convictions about the virtues of entrepreneurial development for the 'public interest'. It was not until the upsurge of the massive social protest in 2011 that urban mobilisations began to address the systemic elements of tower planning and to demand alternatives.

According to Mayer (2013), one of the legacies of the period following the 2008 financial crisis has been that demands with regards to 'the right to the city' in the global North, have refocused from professionalised and consumer-based claims into counter-hegemonic forms of resistance against the institutional methods and decisions 'that produce urban space' (Purcell, 2003, 577). This qualitative shift was enabled by the fact that austerity policies and deepening socio-spatial polarisation within cities are affecting not only the marginalised urban 'outcasts' but also societies' youth, students and the middle classes (Mayer, 2013, 10-11). These groups have created the possibility of new coalitions, bolder mobilisation strategies, and a reframing of the apolitical rhetoric of the consumer and professional citizen into broader claims for social redistribution (see also Bodnar, 2015). Nowadays, Mayer observes, 'urban activism on both sides of the Atlantic finds itself surrounded, in some places inspired, periodically swept up in and often supported by movements like the Indignados or Occupy. These groups pose new practical and political challenges as well as opportunities' (Mayer, 2013, 6).

6 For examples of critiques published in local newspapers (in Hebrew), see A. Ayalon, Ha'aretz, February 23, 1962; I. Vinkler, Ha'aretz, April 11, 1971; A. Erlik, Ha'aretz, September 9, 1975; E. Dotan, Ha'ir, March 7, 1997. 
We take Mayer's observations as a starting point from which to examine what dimensions of urban development are challenged nowadays in Tel Aviv, by whom, and how. How do they relate to the local version of 'centralised entrepreneurialism' and to previous repertoires of resistance? Which types of justification are mobilised and to what extent do they depart from the institutional justifications? Finally, what type of 'crisis' are they alluding to, and to what effect?

The Yizhak Elhanan Towers: Old Strategies, New Claims, Gentrifiers' Crisis

Scholars of social mobilisations argue that the 'judicialisation' of social protest during the 1990s has resulted in it becoming increasingly disciplined and depoliticised (Scheingold and Sarat, 2004). Our first case study shows, however, that the law-as an institutional mechanism and type of discourse-can be also mobilised in ways that challenge the core of the local neo-liberal development project where other mobilisation channels and strategies have failed.

This case concerns the high-rise ventures built around the historic neighbourhood of Neve Tzedek. Ever since these ventures had been planned, the neighbourhood's residents consistently objected to the towers, claiming that they would disregard the historic cityscape, create environmental hazards, and overload the already poor public facilities and infrastructure of the area. These claims were repeatedly rejected by municipal and regional planning committees, which maintained that the ventures advanced the positive urban regeneration dynamic. ${ }^{7}$ However, as we will show next, it was the official rejection of this NIM BY type of claim that led the residents to reframe their grievances and challenge the legitimacy of spot-zoning policies and the PP transactions that would lead to the building of the towers, through the courts.

These citizens were a mixed group: upper middle class and professionals of the creative class who organised themselves into the 'Neve Tzedek Association' and the neighbourhood's 'Parents' Group' but also residents from adjacent districts inhabited historically by lower-class Oriental Jews. Equipped with know-how regarding planning practice and with legal representatives, the first group played a leading role in the mobilisation. The driver for the residents' discontent relates to a major shift in the planning of the area and concomitantly in the privileged position that they had enjoyed until then in the sociospatial regime. In the 1980s, the municipality encouraged the preservation and

7 The head of the regional planning committee, in a letter to the Neve Tzedek residents' association, 18.11.2010; Regional Planning Committee decision regarding objections to planning scheme 2615 (Yizhak Elhanan) b and c 13·7.2011, 14.7.2011. 
renovation of historical districts with small, old, family houses. These efforts gave rise to a bold gentrification process in Neve Tzedek. The neighbourhood became one of the upscale areas of the city, but still suffered from a lack of public and education facilities because the district's schools had been transformed into cultural and artistic centres that aligned with the boho rebranding of the area. The well off newcomers demanded time and again that a school be built and infrastructure improved, but to no avail.

In 2006, the struggle against the encroaching wave of luxury towers planned for the area escalated. These towers constituted a new wave of 'plutocratic' gentrification that threatened to displace the upper middle classes' rights to and privileges in the city. The first tower built in the area-the 'Nechushtan' tower-was completed in 2007, boasting 44 floors. The residents' environmental and aesthetic objections to it were rejected and their demands for infrastructure went unanswered. As the head of the municipal planning team for the central area explained to a real estate journalist in June 2009: 'In reality, the city does not have the money to buy lands for public uses. These parcels are occupied and the purpose of towers' planning is to create public spaces.' (Margalit, 2014, 79).

This tower became emblematic of future struggles as the construction of several other high-rises in the area was approved or planned in the following years. In May 2009, the local planning committee approved the construction of a high-rise on the site of a former chocolate factory south of Neve Tzedek (Shiloh, 2011). Residents objected and though a judge's decision supported their arguments, he noted that the court cannot rule in planning matters. In 2011, plans for the Yitzhak Elhanan Projects pushed the conflict surrounding towers in the area one step further, tying them more clearly to the entrepreneurial deals made by the municipality. These projects were advanced through a series of complementary schemes. The A Plan (2615a) was intended to 'strengthen the residential area' between Neve Tzedek and adjacent historic neighbourhoods (Tel Aviv Regional Committee, 2006, plans objectives, 1), and to transform Yitzhak Elhanan Street into the main commercial thoroughfare between the СвD and the beach. The plan included a 29-floor tower with spacious apartments and private leisure facilities. In exchange, the developers were to create spaces for a kindergarten, a small synagogue and a small public garden.

In the same period, the spot-zoning plan Yitzhak Elhanan B (2615b) was drafted 'to encourage $\mathrm{CBD}$ use and urban renewal' in the area located between the Yitzhak Elhanan A tower and the СвD (Tel Aviv Regional Committee, 2006, 2). The scheme included a 28 -floor tower, half of which was designated for luxury apartments. Public side benefits included the partial widening of the 
street and the preservation of one historic building. One of the architects that planned these projects explained that, as Tel Aviv is becoming denser, Neve Tzedek is becoming a low-density 'island in an urban ocean', adding 'Residents of Neve Tzedek enjoy low-rise construction, but they cannot force themselves on the entire city. To preserve spaces and nature around the city, one has to create density and therefore turn the relatively low-rise construction of the past into taller building' (Shiloh, 2011).

Following the 'deal logic' of entrepreneurial centralism, planners drafted two additional schemes that designated additional floors to towers ' $\mathrm{A}$ ' and ' $\mathrm{B}$ '. In exchange for 11 more floors for the latter, they demanded from the developer the evacuation of a public lot in order to build the public school that the neighbourhood residents had been demanding for so many years (Tel Aviv Regional Committee, 2015). At this point, the neighbourhood committee submitted its objections to the regional planning committee arguing against the spot zoning and the deals that the municipality strikes with developers. 'The city approves high-rise after high-rise due to pressure from developers and the improvement taxes the projects generate, argued one of the organisers of the Neve Tzedek residents' association, 'It's already been decided that the Neve Tzedek Tower was a horrible mistake, yet they're continuing to plan additional towers' (Shiloh, 2011). In response, the district planner said that those who were objecting, who were generally well off and had the means to fight developers, must understand they are just one of a number of legitimate interest groups (Shiloh, 2011). Finally, the planning committee gave in to the appeal and 'recalculated' the developers' costs and benefits, lowering the height of the tower by three floors. It was at this point that the residents' committee decided to go to court, this time enlarging both the scope and framing of their claims.

In claims submitted to the regional court in September 2011, the committee argued that measuring public benefits against floor ratios was illegitimate and that it was the state's obligation, and not the private developer's, to provide public goods. In its response, the municipality argued that such transactions are indispensable for effective urban regeneration. ${ }^{8}$ In 2013, the regional court accepted the residents' claim arguing that according to the Israeli Planning and Building Law, the creation of financial engines for public tasks is not under planning institutions' jurisdiction and that municipal tasks are mandatory and their provision should not be conditioned on being subsidized by the taxes exacted from developers.

8 All claims are elaborated in the verdict regarding petition no. 47348-o9-11, signed January 15, 2013 . 
The legitimation issues raised in this case were thus novel in that they brought into a court, for the first time, what had been the cornerstone of local planning's doxic common sense-namely, developments' side benefits and the exactions made to 'compensate' the public for the erection of massive and expensive new towers. However, long durée entrepreneurial 'habits' and power relations cannot be easily undone. The municipality appealed to the Supreme Court of Justice arguing that all spatial development is based on the principle of exactions from PP ventures, that PP planning as a method for increasing municipal revenues is a just means to an end, and that they can grant the extra floor permits and decide what would be the side benefits. ${ }^{9}$ Finally, the court declined to discuss the appeal; the Elhanan Projects have been built to their full height, and are showcased as part of the municipality's efforts to offer housing solutions..$^{10}$ Neve Tzedek's affluent residents did not get their school. However, their appeal against 'the way of getting things done' set a court precedent and pioneered a debate on the (legal) legitimacy of PP practices-and on the jurisdictions, criteria, and duties of planning in the city— that has wider repercussions.

\subsection{POPS Group: New Strategies, Old Claims, Professional Crisis}

The second case relates to a group of young architects and planners who focused their activism on POPS. POPS are one of the oxymoronic recipes advanced as side benefits of PP ventures for public space 'regeneration' and 'securitisation' (Bodnar 2015, 2096). The group crystallised in 2014 when architect and web journalist Naama Riva published a survey showing the low usage levels and pedestrian traffic in local POPs, and then invited her Facebook followers to join her in picnics in the sanitised and unwelcoming POPs located next to luxurious towers (Riba, 2013). The aim of the group was to mobilise public awareness against the poor service these spaces offer the public and, in the spirit of the 2011 nationwide 'social protest' that inspired the group, to raise the question 'who is getting what and why' in the city.

'These ventures [the towers] gain extended building rights. To 'compensate' the public for this, the developers are obligated to give presents [...] The local planning milieu let entrepreneurs shape it, in manners that only serve their clientele in expensive towers.' With their picnics they thus aimed 'first, to make the public realize that these spaces are theirs by law. Second, to advance the understanding of bureaucrats, planners and the wider public that open

9 Municipality's appeal, no. 1366/11, submitted to the Supreme Court on February 19, 2013.

10 Kerem Israel, In the heart of Tel Aviv, http://www.kerem-israel.info/new_projects/white -city (accessed on 2 December 2016). 
spaces are significant for the city, and that they are threatened by this practice' (Naama Riva interviewed by Noifeld (2014a), our transl.).11

Therefore, alongside the picnic events, the group also launched a public campaign via the conventional media and several blogs, to explain the obscure technical language used by planners and expose how planning decisions that produce unfair spaces are made. The name of the group, Hana'a B'zika, was a successful gimmick that simultaneously hinted at the members' professional expertise and criticised the incomprehensible professional jargon that replaced traditional land expropriation through the usage of new 'publicprivate' terminology. In Hebrew, the name means literally 'joy in a POPs', and also - with its elements transposed-Zikat Hana'a, the legal term for that part of a private plot designated for public passage and usage.

Social activism among young planners and architects like those who created the POPs group is relatively new in Israel. Throughout the first decade of the twenty-first century, professionals created several non-governmental organisations (NGOs) that contested development and environmental policies through advocacy, litigation, and consultation activities (Yacobi, 2007; Alfasi and Fenster, 2014). These organisations opened the way for a discourse with regard to planning that challenged the self-assured language of 'professional knowledge' used by planning authorities (see Margalit and Kemp, 2015) and their constant reference to a 'phantom public interest' (Bodnar, 2015, 2098). Likewise, the POPS activists viewed the planning establishment as submissive to the restraints imposed on it by market-led governments, and at the same time patronising. In Riva's terms, the local municipal planning discourse is 'almost confidential, with very little public exposure', while 'they actually function as interior designers or rubber stamps' to market demands (Noifeld, 2014a). However, in contrast to the NGOs that preceded them, which introduced new critiques but also 'NGOised' the field of activism with regards to planning (Yacobi, 2007), POPS activists aimed at reaching broader publics, by using bolder strategies of direct action and social media.

The POPS group's critique of the planning establishment and its search for new forms of activism expressed its members' sense of personal and professional crisis as young planners trying to make an impact on the public space and, simultaneously, to afford to remain in the expensive city. Inspired by the Occupy and Indignados movements in Tel Aviv and elsewhere, the activists focused on 'hacking' the urban space, reclaiming it for uses that defy its underlying, dominant entrepreneurial logic (Bodnar, 2015, 2100). The actual picnics

11 See also Noifeld (2014b) about a picnic in the front yard of Shari Arison, the owner of the largest Israeli bank. 
took place over six consecutive weekends during the winter of 2014-15 and created the atmosphere of an 'urban guerrilla' happening (see Lugosi et al., 2010). The organisers asked participants to 'bring tables and folding chairs and also a smoking barbecue' to disrupt the complacent calmness of the POPs. ${ }^{12}$ Activists made frequent allusions to the 'cold' sterility of the towers, emphasising their estrangement from the humming streets of the surroundings: 'We considered setting on fire the wooden benches', one of the organisers wrote jokingly, 'I fully understand young kids that vandalize the benches in public gardens and set them on fire. The planning of the public space in (most) Israel is meant to repress the soul of human beings. We've been doing this only for two weeks and we feel already like burning something.'13

The picnics were held in central locations where they could attract crowds and media exposure. The first and second events took place near busy commercial areas, where the mere gathering of participants demonstrated how deserted the POPs usually were. The third event was much bigger, and the police intervened. The site, near the Neve Tzedek Tower, had bred much local resentment throughout the planning process concerned (see above). The picnic clearly surprised the tower's residents, who called the police, earning the group widespread media coverage. When the organisers explained the POPS designation of the site-with the help of Knesset member (and former city council member) Tamar Zandberg, who attended the event- the officers promptly left. On a later prime-time TV show, Zandberg praised the picnickers' efforts, explaining that while the government is supposedly working to solve the housing crisis, many more plans for isolated towers and POPS are actually shaping the urban future. ${ }^{14}$

Up until this point, the organisers had intentionally focused on issues related to the design of POPS rather than on wider problems of neo-liberal development. They claimed that, unlike well-designed pops elsewhere, the local designs minimise public use and create empty areas in the middle of dense neighbourhoods. As Riva explained: 'Instead of making a nice garden or pleasant piazza, they use uncomfortable materials and unwelcoming outlines' (Noifeld, 2014a). Yoav Lerman, another organiser, attributed the poor function of POPS to the lack of public political representation: 'The city council

12 Naama Riba, https://www.facebook.com/naama.riba?fref=ufi (accessed on 2 December 2016).

13 Yoav Lerman, https://www.facebook.com/yoav.lerman?fref=uf. (accessed on 2 December 2016).

14 мАко,http://www.mako.co.il/news-channel2/Economy-Newcast/Article-4elfb3584e7144 1004.htm. (accessed on 2 December.2016). 
members $[\ldots]$ are also responsible for these failures [...] Reading the councils' protocols teaches us that they only consider pops sizes, asking developers, 'Please give me 600 square meters of empty concrete, or 800 square meters.' ${ }^{15}$

Nevertheless, following criticism from participants, the locations of the subsequent picnics were chosen to somehow expand the original mission of the group. The last picnic was in Jaffa, near the Andromeda Cluster, a midsized gated community built in the 1990 s as a Jewish gentrified enclave in the heart of the local Arab community (Monterescu, 2009). By this time, several individuals had invited the picnic group to mobilise in their neighbourhoods and cities, but the group was running out of steam. It was partly rejuvenated a year later through an online community named tlvPOPS, via which Riva and a computer expert, collect and share POPS information.

\section{$5 \quad$ Concluding Discussion}

In this chapter, we set out to examine the ways in which the legitimation crisis of neo-liberalism and its deal logic of the city and its people affect current contestations regarding one of the boldest spatial symbols of entrepreneurial development. The reconfigured urban settings in which neo-liberal ideas and policies have been the subject of experiment and practice worldwide have been crucial to the successful adaptation and reproduction of neo-liberalism (Kunkel and Mayer, 2012, 3). In this context, politicians and pundits promote luxurious towers and megaprojects as a major driver for urban economic development and regeneration (Grubbauer, 2014), a precondition for global entrepreneurial competition (Sklair and Gherardi, 2012), and a means of making private money 'work' in the public interest (Enright, 2014). However, as we have shown, these towers have become both a site and a medium of social contention. Conflict around towers has accentuated in the current phase of neo-liberalisation, shaking the apolitical apathy of consumer- and professional-based urban claims characteristic of previous phases. As Mayer (2013) observes, movements like the Indignados and Occupy have created a window of opportunity for the politicisation of current forms of urban activism

15 Yoav Lerman (2014) 'Another Blog from Tel Aviv', 5 February, http://tlvi.co

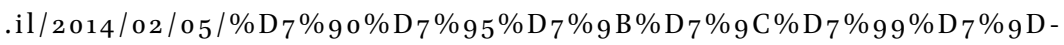

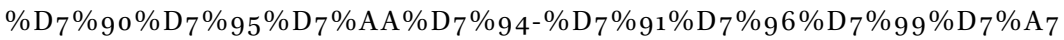

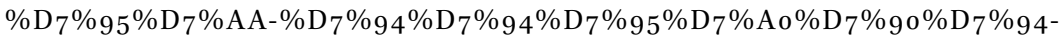
\% D 7 \% ${ }_{1} \% \mathrm{D}_{7} \%{ }_{9} 9 \% \mathrm{D}_{7} \%{ }_{9} \% \mathrm{D}_{7} \%{ }_{9} \mathrm{D}$ - \% D 7 \% A 9 \% D 7 \% A 9 \% D 7 \% 99 $\% \mathrm{D}_{7} \% 91 \% \mathrm{D} 7 \% \mathrm{A6} \% \mathrm{D} 7 \% 94 /$ (accessed on 28 July 2016). 
in many of the affluent urban nodes, by introducing new strategies, claims and coalitions.

Our case studies largely confirm that the 'spectre' of crisis hovers over current mobilisations in Tel Aviv; it does so, however, following the particular assemblages of local neo-liberalisation. The local version of urban entrepreneurialism in Tel Aviv involves a strong centralism that is supported by institutionalised power settings and justified by the side benefits of PP ventures for urban regeneration and beautification. Side benefits and P P negotiations have thus become the main object of current local contestations. Yet, as we have shown, contestations have also been shaped by the actors concerned, their positions, and the ways in which they imagine what development is or can be.

Regarding the actors, their modes of mobilisation and positions, we found that, equipped with financial and social capital, the Neve Tzedek residents used conservative means of judicial mobilisation while radicalising previous NIMBY claims against towers. Their struggle was conducted from the position of upscale gentrifiers who, in the past, had benefited from the privileges of urban development but had now lost faith in the system and its distributive politics. The POPS youngsters resorted to creative means of mobilisation by physically reclaiming public space across the city. Occupying space and explaining how it is produced, they aimed to distinguish their professional selves from generations of older planners working for the establishment and private firms. In the activists' view, these older professionals have betrayed their mission by becoming mere 'interior designers' or 'rubber stamps', submissive to market-rule and governance.

The language of current contestations also showed continuity with the 'social justice' protest of 2011. The grievances in Neve Tzedek began way before the social protest; nevertheless, the neighbourhood committee's appeal on the Yitzhak Elhanan Projects aligned with the broader redistributive claims raised by the popular protest. Thus, they reframed their claims in universalising terms of urban citizenship, arguing that the law mandates 'City Hall' to provide public services and infrastructure directly to citizens and not through conditional 'side benefits' issuing from PP negotiations. The POPS group was created a couple of years after the local tent camp protest had been dismantled. Nevertheless, the POPS activists presented their mobilisation as part of the wider struggle for the right to urban spaces and for more equitable planning. In that sense, both mobilisations addressed the same crucial questions-who gets what, and why, and how public decisions are made - seeking to disclose the systematic ways in which uneven and non-democratic development is created.

Nevertheless, our case studies also showed the fragmented and limiting dynamics that struggles for rights to the city and against market rule often display. 
As Blokland et al. argue, 'whereas the organising of citizens for their right to the city constitutes a counterforce against corporate and ethnonationalistic influences on urban policies, such claims $[. .$.$] are often strikingly specific re-$ garding their thematic focus and the groups they speak for' $(2015,656-657)$. Our case studies show that raising overall claims to public space and denouncing the corrupting market logic of urban policies often obscure rather than overcome the multilayered conflicts of urban development and inequality. Gentrifiers in Neve Tzedek reclaimed their 'republican' rights to public services as discontented urban citizens endowed with a clear sense of deservedness (Marcuse, 2009). Yet they limited their claims to the methods of producing 'side benefits' through towers, without touching upon the harsh dividing impacts neo-liberal development has on the undeservedly dispossessed in the city (Marcuse, 2009). Their appeal did indeed produce a meaningful judicial precedent, but its impact on later schemes has so far been minimal, as policymakers continue promoting the competitive agenda with promises of future 'trickle-down' impacts for other 'legitimate' interest groups.

Similarly, when the POPS organisers strategically chose to focus their message on the 'design' of the POPS, they actually set the parameters of their protest: 'It seems impossible to fight the major economic forces now working in Israel's urban centres, especially in Tel Aviv', explained Riva, 'It is possible, though, to reject the destruction of the street level' (Noifeld, 2014a). When participants challenged them to address broader issues of segregation and argued that on-site actions cannot ignore the history of a place and its former residents, these challenges were disregarded. 'Perhaps in the war on tycoons, Huldai and luxury towers, we should cooperate with Palestinians [...] and Mizrachim (Oriental Jews), stated one of the participants in the picnic held in an exclusive enclave of towers built on the remains of a Jewish slum and a former Palestinian village, 'after all, their slums are also in danger of takeover.'16 But the idea of creating broader coalitions was rejected on the grounds that 'there is no difference between former Jewish, German, or Arab lands, what drives the building of towers in Tel Aviv and Israel, is only one thing. Money.' In this manner, their critique of the 'power of money' as erasing the public space was based on the erasure of the many class, ethnic, and national divisions that make up the public and that public's different demands and needs in Tel AvivJaffa (see Marom, 2014).

A similar dynamic of universalised claims to rights to the city that misrecognise the particularities of the activists involved (Harvey, 2005) was manifest

16 Asaf Even-Chen, 14 December 2014, comment, facebook event page Hannaa Bazika no. 4, https://www.facebook.com/events/746169022067573/?active_tab=discussion. 
in the group invocation of a binary image of the 'rich' tower dwellers and the general and largely indifferent 'public', waiting to be enlightened: 'People have little interest in planning matters, which they also hardly understand, we need to explain and focus their attention' (Noifeld, 2014a). In that sense, the POPS discourse remained closer to the planning milieu's discourse - on a 'general public interest' - that it set out to challenge, and it thus undercut the activists' radical potential and actual impact.

Moreover, similar to the self-limited critique of their Neve Tzedek counterparts, the POPS group avoided dealing with the deeper troubles of local neo-liberalisation. While they exposed the methods that privatise the right to urban space, the alternatives they proposed relied on the 'new urbanism' idea that 'good' urban design is the best means of achieving social mixture and social justice (Alfasi and Fenster, 2014). In this manner, both groups clearly challenged the ethos and modus operandi of entrepreneurial development as a form of socio-economic redistribution, yet to a large degree their critique remained trapped in the fragmenting dynamics that feeds neo-liberalisation as an ongoing form of 'dividing and ruling' society while re-engineering its multilayered social divisions.

Looking at urban development through the prism of its challengers thus brings insight into the non-binary articulations between conflict and development. A close-up look into the politics of contention regarding urban development - the mobilisation strategies of challengers, the ways in which they frame what are the wrongs of development and what ought to be done about them, and the social position from which they articulate their discontent-reveals that contestations can actually highlight the deeper layers of consensus that make neo-liberalisation processes so resilient, even when the latter are allegedly experiencing a 'legitimation crisis'.

\section{References}

Aalbers, M.B. (2013) 'Neoliberalism is Dead ... Long Live Neoliberalism!' International Journal of Urban and Regional Research, 37(3), pp. 1083-1090, DOI: 10.1111/1468-2427.12065.

Alexander, E.R. (2002) 'The Public Interest in Planning: From Legitimation to Substantive Plan Evaluation', Planning Theory, 1(3), pp. 226-249, DOI: 10.1177/147309520200100303.

Alfasi N. (2006) 'Planning Policy? Between Long-term Planning and Zoning Amendments in the Israeli Planning System', Environment and Planning A, 38(3), pp. 553-568, DOI:10.1068/a37335. 
Alfasi, N. and T. Fenster (2014) 'Between Socio-spatial and Urban Justice: Rawls' Principles of Justice in the 2011 Israeli Protest Movement', Planning Theory, 13(4), pp. 407-427, DOI:10.1177/1473095214521105.

Alterman, R. (1990) 'From Expropriations to Development Agreements: Developer Obligations for Public Services in Israel', Israel Law Review, 24(1), pp. 29-81, DOI: 10.1017/Soo2122370000978X.

Blokland, T., C. Hentschel, A. Holm, H. Lebuhn and T. Margalit (2015) 'Urban Citizenship and Right to the City: The Fragmentation of Claims', International Journal of Urban and Regional Research, 39(4), pp. 655-665, DOI: 10.1111/1468-2427.12259.

Bodnar, J. (2015) 'Reclaiming Public Space', Urban Studies, 52(12), pp. 2090-2104, DOI: 10.1177/0042098015583626.

Booth, P. (1995) 'Zoning or Discretionary Action: Certainty and Responsiveness in Implementing Planning Policy', Journal of Planning Education and Research, 14(2), pp. 103-112, DOI: 10.1177/0739456X9501400203.

Brenner, N., J. Peck and N. Theodore (2010) 'Variegated Neoliberalization: Geographies, Modalities, Pathways', Global Network, 10(2), pp. 182-222, DOI: 10.1111/j.1471-0374.2009.00277.x.

Brenner, N. and N. Theodore (2002) 'Cities and the Geographies of "Actually Existing Neoliberalism"', Antipode, 34(3), pp. 349-379, DOI: 10.1111/1467-8330.00246.

Burningham, K. and D. Thrush (2001) 'Rainforests are a Long Way from Here': the Environmental Concerns of Disadvantaged Groups (York: Joseph Rowntree Foundation).

Cullingworth, B. (1993) The Political Culture of Planning (New York: Routledge).

Crot, L. (2006) "Scenographic" and "Cosmetic" Planning: Globalization and Territorial Restructuring in Buenos Aires', Journal of Urban Affairs, 28(3), pp. 227-251, DOI: 10.1111/j.1467-9906.2006.00290.x.

Dirlik, A. (2005) 'Architectures of Global Modernity, Colonialism, and Places', Modern Chinese Literature and Culture, 17 (1), pp. 33-61.

Dixon, M. (2010) 'Gazprom versus the Skyline: Spatial Displacement and Social Contention in St. Petersburg', International Journal of Urban and Regional Research, 34(1), pp. 35-54, DOI: 10.1111/j.1468-2427.2009.00871.x.

Ellis, G. (2004) 'Discourses of Objection: towards an Understanding of Third-party Rights in Planning', Environment and Planning A, 36(9), pp. 1549-1570, DOI: 10.1068/ a36176.

Enright, T. (2014) 'Illuminating the Path to Grand Pari(s): Architecture and Urban Transformation in an Era of Neoliberalization", Antipode, 46(2), pp. 382-403, DOI: 10.1111/anti.12048.

Fainstein, S. (2008) 'Mega-projects in New York, London and Amsterdam', International Journal of Urban and Regional Research, 32(4), pp. 768-785, DOI: 10.1111/j.1468-2427.2008.00826.x. 
Fox Gotham, K. (2001) 'Urban Redevelopment, Past and Present' in K. Fox Gotham (ed.), Critical Perspectives on Urban Redevelopment, (Bingley: Emerald Group Publishing Limited), pp. 1-31.

Fox-Rogers, L. and E. Murphy (2015) 'From Brown Envelopes to Community Benefits: the Co-option of Planning Gain Agreements under Deepening Neoliberalism', Geoforum, 67, pp. 41-50, DOI:10.1016/j.geoforum.2015.09.015.

Fuller, C. (2012) 'Urban Politics and the Social Practices of Critique and Justification: Conceptual Insights from French Pragmatism', Progress in Human Geography, 37(5), pp. 639-657, DOI: 10.1177/0309132512469763.

Gielent, D.M. and T. Tasan-Kok (2010) 'Flexibility in Planning and the Consequences for Public-value Capturing in UK, Spain and the Netherlands', European Planning Studies, 18, pp. 1097-1131, DOI: 10.1080/o9654311003744191.

Graham, S. and S. Marvin (2001) Splintering Urbanism: Networked Infrastructures, Technological Mobilities and the Urban Condition (London and New York: Routledge).

Grubbauer, M. (2014) 'Architecture, Economic Imaginaries and Urban Politics: The Office Tower as Socially Classifying Device', International Journal of Urban and Regional Research 38(1), pp. 336-359, DOI: 10.1111/1468-2427.12110.

Harvey, D. (2005) A Brief History of Neoliberalism (Oxford: Oxford University Press).

Harvey, D. (1989) 'From Managerialism to Entrepreneurialism: the Transformation of Governance in Late Capitalism', Geografiska Annaler. Series B, Human Geography, 71(1), pp. 3-17, DOI: 10.2307/490503.

Hatuka, T. and L. Forsyth (2005) 'Urban Design in the Context of Glocalization and Nationalism: Rothschild Boulevards, Tel Aviv', Urban Design International, 10(2), pp. 69-86, DOI:10.1057/palgrave.udi.90oo142.

Heeg, S. and M. Rosol (2007) 'Neoliberale Stadtpolitik im globalen Kontext, Ein Überblick' Prokla, 149, pp. 491-510, https://www.uni-frankfurt.de/46211933/Heeg Rosol_2007.pdf (accessed on 27 July 2016).

Keil, R. (2009) 'The Urban Politics of Roll-with-it Neoliberalization', City, 13(2-3), pp. 230-245, DOI: $10.1080 / 13604810902986848$.

Kemp, A. and R. Raijman, (2004) “Tel Aviv is not Foreign to You”: Urban Incorporation Policy on Labor Migrants in Israel', International Migration Review, 38(1), pp. 26-51, DOI: 10.1111/j.1747-7379.2004.tboo187.x.

Künkel, J. and M. Mayer (eds) (2012) Neoliberal Urbanism and Its Contestations: Crossing Theoretical Boundaries (Basingstoke: Palgrave Macmillan).

Leiper, N. and S-Y. Park (2010) 'Skyscrapers' Influence on Cities' Roles as Tourist Destinations', Current Issues in Tourism 13(4), pp. 333-349, DOI: 10.1080/13683501 003748047.

Loftman, P. and B. Nevin (1995) 'Prestige Projects and Urban Regeneration in the $1980 \mathrm{os}$ and 1990s: A Review of Benefits and Limitations', Planning Practice and Research, 10(3-4), pp. 299-316, DOI: 10.1080/02697459509696280. 
Lugosi, P., D. Bell and K. Lugosi (2010) 'Hospitality, Culture and Regeneration: Urban Decay, Entrepreneurship and the "Ruin" Bars of Budapest', Urban Studies, 47(14), pp. 3079-3101, DOI: 10.1177/0042098009360236.

Marcuse, P. (2009) 'From Critical Urban Theory to the Right to the City', City, 13(2-3), pp. 185-197, DOI: 10.1080/13604810902982177.

Margalit, T. (2014) 'Multi-Spot-Zoning: a Chain of Public-private Development Ventures in Tel Aviv', Cities, 37(C), pp. 73-81, DOI: 10.1016/j.cities.2013.12.001.

Margalit, T. (2013) 'Land, Politics and High-Rise Planning: Ongoing Development Practices in Tel Aviv-Yafo', Planning Perspectives, 28(3), pp. 373-397, DOI: 10.1080/02665433.2013.737713.

Margalit, T. and A. Kemp (2015) Justifying Planning Decisions: Institutional Response to Planning Objections in Israel, Conference Paper (Prague: Conference AESOP), DOI: 10.13140/RG.2.1.3242.2248.

Margalit, T. and E. Vertes (2015) 'Planning Allocations and the Stubborn North-South Divide in Tel Aviv-Jaffa', Planning Theory and Practice, 16(2), pp. 226-247, DOI: 10.1080/14649357.2015.1026925.

Marom, N. (2014) 'Relating a City's History and Geography with Bourdieu: One Hundred Years of Spatial Distinction in Tel Aviv', International Journal of Urban and Regional Research, 38(4), pp. 1344-1362, DOI: 10.1111/1468-2427.12027.

Marshall, R. (2003) Emerging Urbanity: Global Urban Projects in the Asia Pacific Rim (New York: Spon Press).

MacLeod, G. (2002) 'From Urban Entrepreneurialism to a "Revanchist City"? On the Spatial Injustices of Glasgow's Renaissance', Antipode, 34(3), pp. 602-625, DOI: $10.1111 / 1467-8330.0025^{6}$.

Mayer, M. (2013) 'First World Urban Activism', City, 17(1), pp. 5-19, DOI: 10.108o/ $13604813.2013 \cdot 757417$.

McNeill, D. (2002) 'The Mayor and the World City Skyline: London's Tall Buildings Debate', International Planning Studies 7 (4), pp. 325-334, DOI: 10.1080/135634702200 0027747 .

Monterescu, D. (2009) 'To Buy or Not to Be: Trespassing the Gated Community', Public Culture, 21(2), pp. 403-430, DOI: 10.1215/08992363-2008-034.

Nicholls, W. and F. Vermeulen (2012) 'Rights through the City: The Urban Basis of Immigrant Rights Struggles in Amsterdam and Paris', in Smith, M.P. and M. McQuarrie (eds) Remaking Urban Citizenship: Organizations, Institutions, and the Right to the City (New Brunswick, NJ: Transaction Publishers), pp. 10-79.

Noifeld, A. (2014a) 'A meal in Zikat Hana'a-Interview of Naama Riva, Slow, Tel Aviv, http://slow.org.il/2014/o1/28/\%D7\%9o\%D7\%A8\%D7\%95\%D7\%97\%D7\%94-\%D7

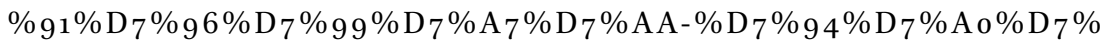
90\% $\mathrm{D}_{7} \% 94-2$ (accessed on 28 July 2016). 
Noifeld, A. (2014b) 'A picnic in the front yard of Shari Arison', Haaretz, o8 February, http:// www.haaretz.co.il/magazine/tozeret/.premium-1.2237427 (accessed on 28 July 2016).

Peck, J., N. Theodore, and N. Brenner (2013) 'Neoliberal Urbanism Redux?' International Journal of Urban and Regional Research, 37(3), pp. 1091-9, DOI: 10.1111/1468-2427.12066.

Peck, J., N. Theodore and N. Brenner (2009) 'Neoliberal Urbanism: Models, Moments, Mutations', The SAIS Review of International Affairs, 29(1), pp. 49-66, DOI: 10.1353/ sais.0.0028.

Purcell, M. (2003) 'Citizenship and the Right to the Global City: Reimagining the Capitalist World Order', International Journal for Urban and Regional Research, 27(3), pp. 564-591, DOI: 10.1111/1468-2427.00467.

Riba, N. (2013) 'Residents of Tel Aviv- Please do not disturb towers' residents' towers', XNET, 15 December, http://xnet.ynet.co.il/architecture/articles/o,14710,L-3103771,00. html (accessed on 2 December 2016).

Sagalyn, L.B. (2007) 'Public/Private Development', Journal of the American Planning Association, 73(1), pp 7-22, DOI: 10.1080/01944360708976133.

Sager, T. (2011) 'Neo-liberal Urban Planning Policies: A Literature Survey 1990-2010', Progress in Planning, 76(4), pp. 147-199, DOI: 10.1016/j.progress.2011.09.001.

Saito, A. (2003) 'Global City Formation in a Capitalism Development State: Tokyo and the Waterfront Sub-centre Project', Urban Studies, 40(2), pp. 283-308, DOI: $10.1080 / 00420980220080281$.

Scheingold, S. and A. Sarat (2004) Something To Believe In: Politics, Professionalism and Cause Lawyering (Stanford: Stanford University Press).

Schipffer, S. (2015) 'Urban Social Movements and the Struggle for Affordable Housing in the Globalizing City of Tel Aviv-Jaffa', Environment and Planning A, 47, pp. 521-536, DOI: 10.1068/a140249p.

Shiloh, S. (2011) 'Towers of Contention' Haaretz, Jan 31, http://www.haaretz.com/printedition/business/towers-of-contention-1.340261 (accessed on 27 July 2016).

Sklair, L. and L. Gherardi (2012) 'Iconic Architecture as a Hegemonic Project of the Transnational Capitalist Class', City, 16(1-2), pp. 57-73, DOI: 10.1080/13604813.2012.662366.

Stone, C. (1993) 'Urban Regimes and the Capacity to Govern: A Political Economy Approach', Journal of Urban Affairs, 15(1), pp. 1-28, DOI: 10.1111/j.1467-9906.1993. tboo30o.x.

Swyngedouw, E., F. Moulaert and A. Rodriguez (2002) 'Neoliberal Urbanization in Europe: Large-scale Urban Development Projects and the New Urban Policy', Antipode, 34(3), pp. 542-577, DOI: 10.1111/1467-8330.00254.

Tasan-Kok, T. (2008) 'Changing Interpretations of "Flexibility" in the Planning Literature: From Opportunism to Creativity?' International Planning Studies, 13(3), pp. 183-195, DOI: 10.1080/13563470802521382. 
Tel Aviv Regional Committee (2015), Planning scheme no. 2615c, http://mavat.moin .gov.il/mavatps/forms/SV4.aspx?tid=4 (accessed on 28 July 2016).

Tel Aviv Regional Committee (2006), Planning scheme no. 2615a, http://mavat.moin .gov.il/mavatps/forms/SV4.aspx?tid=4 (accessed on 28 July 2016).

Theodore, N., J. Peck and N. Brenner (2011) 'Neoliberal Urbanism: Cities and the Rule of Markets', in G. Bridge and S. Watson (eds) The New Blackwell Companion to the City (Oxford: Wiley-Blackwell), pp. 15-25.

Vicario, L. and P.M.M. Monje (2003) 'Another 'Guggenheim Effect'? The Generation of a Potentially Gentrifiable Neighborhood in Bilbao', Urban Studies, 40, pp. 2383-400. Weber, R. (2002) 'Extracting Value from the City: Neoliberalism and Urban Redevelopment', Antipode, 34(3), pp. 519-540, DOI: 10.1111/1467-8330.00253.

Willis, C. (1995) Form Follows Finance, Skyscrapers and Skylines in Chicago and New York (New York: Princeton Architectural Press).

Yacobi, H. (2007) 'The NGOization of Space: Dilemmas of Social Change, Planning Policy, and the Israeli Public Sphere', Environment and Planning D, 25(4), pp. 745-758, DOI: $10.1068 / \mathrm{d} 459$ t. 